\title{
Peace Education as a Systemic Effort to Prevent Radical and Intolerant Behavior in College Students (Descriptive Analysis Study at Universitas Negeri Medan)
}

\author{
$1^{\text {st }}$ Hodriani ${ }^{1}, 2^{\text {nd }}$ Surya Dharma ${ }^{2}, 3^{\text {rd }}$ Halking $^{3}$ \\ \{ Hodriani@gmail.com ${ }^{1}$ \} \\ Department of Pancasila and Civic Education, Faculty of Social Sciences, Universitas \\ Negeri Medan ${ }^{1,2,3}$
}

\begin{abstract}
As a pluralistic nation, the issue of tolerance and radicalism become a problem and a challenge for Indonesia. It is said to be a problem because this behavior can threaten the integrity of the Unitary State of the Republic of Indonesia (NKRI). This behavior does not only occur in society but also students as educated people. For this reason, systematic efforts are needed to prevent radical and intolerant behavior in students through the idea of peace education. This research was conducted at Universitas Negeri Medan using a qualitative approach through descriptive analysis method. The use of this method is expected to explore how the concept of peace education has been implemented Universitas Negeri Medan. The subjects of the research are students and lecturers at Medan State University. The results of the study show that (1) Peace education is a necessity to prevent intolerant behavior and radicalism in students; (2) Peace education can be implemented through various learning activities, especially in the general compulsory subjects Pancasila Education and Citizenship Education; (3) The implementation of peace education through compulsory general subjects Pancasila and Civic Education can be implemented through innovative, challenging and fun learning.
\end{abstract}

Keywords. Peace education, radicalism, intolerance, higher education.

\section{Introduction}

Indonesia's diversity in terms of ethnicity, ethnicity, culture, religion, race and group is a nation's wealth that existed long before Indonesia's independence. On the one hand, this wealth becomes the advantage and capital of the nation's existence, but on the other hand it becomes a threat that triggers conflicts both vertically and horizontally. One form of this threat is radical understanding which causes various acts of terrorism in various regions in Indonesia. Various cases of radicalism related to fanaticism against certain religious sects both locally, regionally and globally are currently a challenge to a peaceful world life [1]. There are indications that this understanding is deliberately cultivated in various levels of society in Indonesia. It is not only ordinary people who are victims, even radicalism is considered to have thrived in educational institutions such as universities. The results of research conducted by Sas, Ponnet, Reniers, \& Hardyns [2] show that some extremist groups agree that educational institutions are attractive places to spread radicalism. The choice of educational 
institutions as a place to develop radical understanding may be due to an inadequate understanding of religious teachings such as Islam [3].

Radicalism is an understanding that is not in accordance with the values of propriety and deviates from the social system and teachings of any religion. This understanding demands social and political change through various acts of violence [4]. According to the National Counterterrorism Agency (BNPT) that radicalism is an attitude that craves total and revolutionary change by overturning existing values drastically through violence and extreme actions [5]. Furthermore, according to Marsudi \& et al, [5] that there are several characteristics that can be recognized from radical attitudes and understandings, namely:

(1) Intolerance (doesn't want to respect the opinions \& beliefs of others), (2) Fanatic (always feel right about yourself; thinks others are wrong), (3) Exclusive (to excel from other groups and shut yourself off from open understanding), and (4) Revolutionary (tends to use violent means to achieve goals)

These four characteristics continue to grow massively and structured by utilizing advances in information, technology and communication. The euphoria of freedom is a way to continue to spread radical ideas to all levels of society. Other traits that we can know include having a change of mind, producing and spreading fake news, and being anti-social. This effort was carried out as a way to destroy the integrity of the Unitary State of the Republic of Indonesia (NKRI). To overcome this, systemic efforts are needed that involve all fields, including education. Because education is considered as the main partner in preventing and fighting radicalization from an early age [2]. From education, various strategies that are considered effective are born to prevent this understanding from growing and developing more widely. Dialogue and educational pathways are two approaches that are considered effective. The results of research conducted by Huda, Haryanto, \& Haryanto, [6] that providing education on diversity is considered effective in preventing radicalism and intolerance in universities. These efforts can be made through various interesting teaching [6].

The results of research conducted by Fatgehipon, Bin-Tahir, Abdullah, Sujarwo, \& Hidayat [7] that project-based learning through the values of local wisdom is considered effective in anticipating radicalism in students. Using local wisdom values is considered effective in solving various national problems in a peaceful, humanistic and respectful manner [7]. In addition, the results of research Syahrul [8] show that radicalism can be prevented by including pluralism and multiculturalism education in the curriculum in universities. The results of this study show that radicalism can be prevented through learning that is able to explore the values of diversity and respect for differences. In a broader context, one alternative in preventing radicalism is through learning that is carried out in a peaceful, humanistic, compassionate, and loving way. This effort can be done through peace education.

Peace education can be used as an alternative in preventing radicalism because it has three objectives, namely (1) peace education as knowledge, namely making it a subject or subject in the curriculum at school; (2) peace education as a set of attitudes and skills taught in the context of education; and (3) a combination of the two, namely as knowledge and a set of attitudes and skills [9]. In this study, the author will examine how peace education is a set of attitudes and skills that can be used as an alternative in preventing radicalism in higher education. Researchers will explore how the values of peace can be instilled in students through various courses that support the strengthening of respect for the values of difference. 


\section{Method}

\subsection{Research Types and Approach}

This study aims to explore peace education based on local wisdom as an effort to prevent radicalism in students. Departing from this goal, this research uses a case study approach. The research was conducted from July to August 2021. Using various data collection techniques such as in-depth interviews, observation, and documentation. The research was conducted at Medan State University. The location selection was based on various considerations, including the State University of Medan, an Education-Based Higher Education which has contributed to the graduation of thousands of teachers who are currently working both in Indonesia and in various countries around the world. Having students with various ethnicities, religions and races makes this university a very plural campus. Departing from this background, the State University of Medan is considered appropriate as a place of research based on its unique characteristics.

\subsection{Portfolio Planning.}

The subjects in this study consisted of 4 lecturers who taught Citizenship Education and Pancasila Education, as well as students from 3 Study Programs, namely Biology Education (5 people), Elementary School Teacher Education (4 people) and Pancasila and Citizenship Education ( 8 people). person). Thus, the number of subjects in this study was 20 subjects. All research subjects were selected based on criteria that understood learning, strengthening tolerance values, diversity, and students as the main subjects in this study.

\subsection{Data Collection}

This study uses various data collection tools such as interviews, observation and documentation studies. Interviews were conducted to explore the understanding of lecturers and students regarding 1) peace education as an effort to prevent radicalism; 2) courses in Higher Education that are in line with the goals of Peace Education; and 3) efforts to explore the value of local wisdom as the basis for implementing peace education.

\subsection{Data Validity and Analysis}

In order for this research to have reliable results, the validity of the research needs to be carried out. Checking the results of this study was carried out using a triangulation model. Triangulation is a method used to synthesize data against the truth by using other data collection methods [10]. The data obtained is then analyzed through four stages, namely data presentation, data reduction, verification, and drawing conclusions. 


\section{Results and Discussion}

The findings of this study are divided into two, namely 1) the role of peace education as an effort to prevent radicalism in Higher Education and 2) Elaboration of Local Wisdom Values in the Implementation of Peace Education in Higher Education.

\subsection{The Results Of The First Study: The Role Of Peace Education As An Effort To Prevent Radicalism in Universities}

To obtain information related to the role of peace education as an effort to prevent radicalism in higher education, researchers conducted interviews with lecturers and students with the following indicators: 1) understanding of peace education; 2) integration of peace education in universities and 3) the urgency of peace education to prevent radicalism in students. The results can be seen in the table below:

Table 1. Description of Interview results the role of peace education as an effort to prevent radicalism in universities

\begin{tabular}{l|c}
\hline \multicolumn{1}{c}{ Subject's Statements } & Subject Code \\
\hline \multicolumn{1}{c}{ Understanding of peace education } & CS 1 \\
\hline $\begin{array}{l}\text { "Efforts are being made to build a more peaceful life by taking into account cultural } \\
\text { differences such as ethnicity, religion, etc." }\end{array}$ & CS 2 \\
\hline $\begin{array}{l}\text { "education that encourages change through the desire to live a more harmonious, } \\
\text { humane, compassionate and non-conflict" }\end{array}$ & CS 3, CS9 \\
\hline $\begin{array}{l}\text { "the process of strengthening attitudes, knowledge, and skills needed for a better world } \\
\text { life" such as preventing conflicts, both real and covert }\end{array}$ & CS4 \\
\hline "humanizing education" & CS5, CS8 \\
\hline $\begin{array}{l}\text { "Systematic efforts to strengthen knowledge, attitudes and skills to be able to live } \\
\text { amidst differences and create a more peaceful life" }\end{array}$ & CS5 \\
\hline $\begin{array}{l}\text { "Education that teaches students to respect differences and prevent conflicts for a more } \\
\text { peaceful, just and compassionate world" }\end{array}$ & CS11 \\
\hline $\begin{array}{l}\text { "education that teaches us to respect each other, peace" } \\
\text { "education that provides peace and prosperity for others so that one can feel justice and }\end{array}$ & CS10 \\
\hline $\begin{array}{l}\text { peace" } \\
\text { Integration of Peace Education in University } \\
\text { rights" }\end{array}$ & \\
\hline $\begin{array}{l}\text { "Through Citizenship Education (PKn) courses because it has the same goal, it is } \\
\text { almost the same as citizenship education, namely the formation of attitudes, knowledge } \\
\text { separate courses or the values can be inserted through other relevant courses" }\end{array}$ & CS6,CS12 \\
\hline $\begin{array}{l}\text { "There are various ways that can be done, for example by forming a peaceful } \\
\text { community as has been done in several countries in the world" } \\
\text { "The participation of policy makers is very much needed to insert peaceful values into } \\
\text { relevant subjects such as Citizenship Education" }\end{array}$ & CS3,CS7 \\
\hline
\end{tabular}




\begin{tabular}{l|c}
\hline and skills" & \\
\hline The Urgency of Peace Education to Prevent Radicalism & \\
\hline $\begin{array}{l}\text { "Peace education is able to prevent radicalism in students because this education } \\
\text { teaches values of peace, compassion, respect for differences, etc." }\end{array}$ & CS10 \\
\hline $\begin{array}{l}\text { "because peace education teaches mutual respect, if you respect each other then there } \\
\text { is a good relationship between each other" }\end{array}$ & CS11 \\
\hline
\end{tabular}

\subsection{The results of the second study: Elaboration of Local Wisdom Values as the basis for the Implementation of Peace Education in Higher Education}

To obtain information related to the elaboration of local wisdom values as the basis for implementing peace education in universities, researchers conducted interviews with lecturers and students. Interviews were conducted to obtain data related to the strategies used to explore the values of local wisdom as the basis for implementing Peace Education in Higher Education as well as appropriate learning models in teaching peace education to students. The results of the interview can be summarized in this figure:

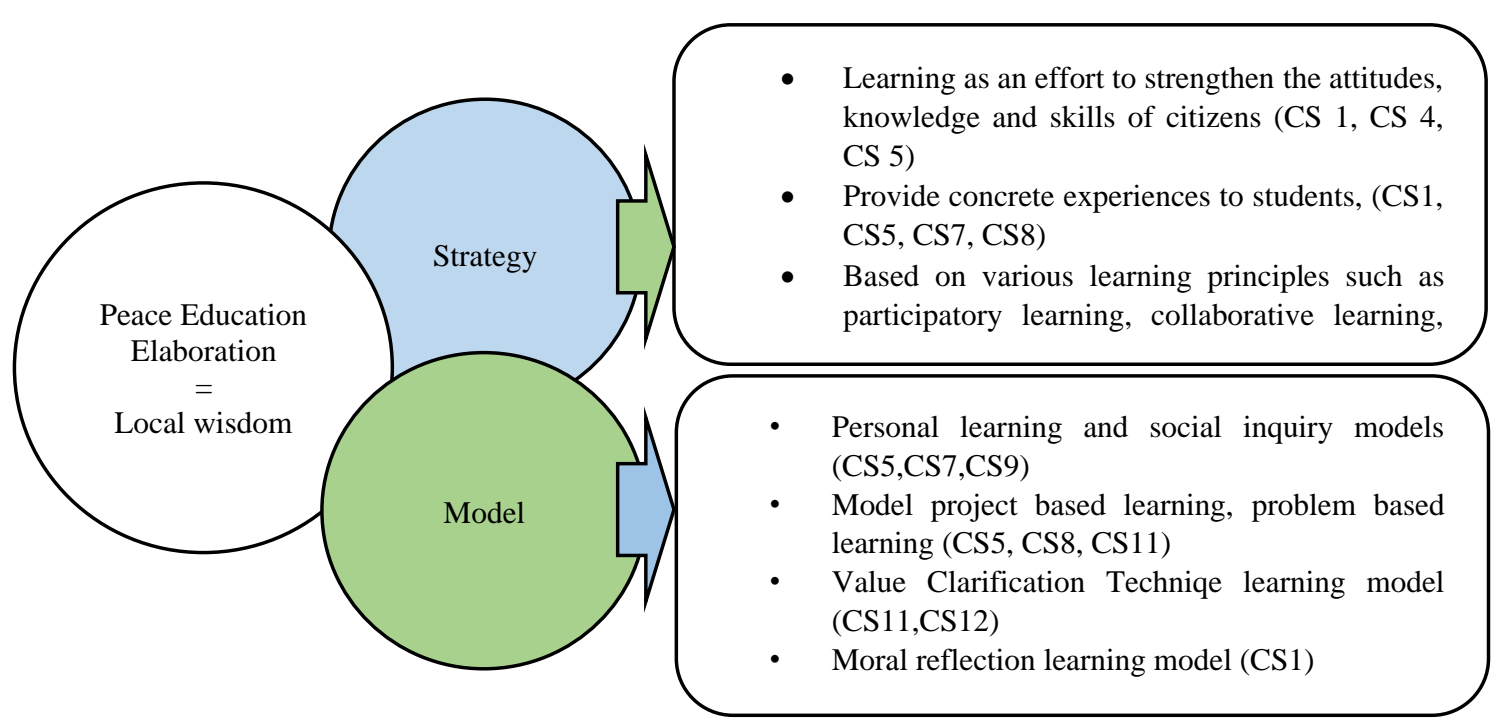

Fig. 1. Elaboration of peace education based on local wisdom values 


\section{References}

[1] Tahir S., Malik A., \& Novrika. Buku Panduan Pencegahan Radikalisme di Lingkungan Kerja BUMN dan Perusahaan Swasta. Jakarta: BNPT, BUMN, Kadin Indonesia. 2020.

[2] Sas M., Ponnet, K., Reniers , G., \& Hardyns , W. The Role of Education in the Prevention of Radicalization and Violent Extremism in Developing Countries. Sustainability. 2020; 12(6):2320

[3] Abdullah, I. Kontruksi dan Reproduksi Kebudayaan. Yogyakarta: Pustaka Pelajar; 2010.

[4] Yamin, M. N Hanifah, M., \& Bakhtiar. Radikalisme di Kalangan Mahasiswa. Supremasi. Jurnal Pemikiran dan Penelitian Ilmu-ilmu Sosial, Hukum, \& Pengajarannya. 2021; XVI(1), 25-35.

[5] Marsudi, et al. Menangkal Radikalisme di Kampus. Surabaya: UNES Surabaya; 2019.

[6] Huda U, Haryanto T, Haryanto BS. Strategi Pengembangan Radikalisme di Perguruan Tinggi Kabupaten Banyumas. An Nidzam. 2018; 5(1): 39-61.

[7] Fatgehipon AH, Bin TSZ, Abdullah K., Sujarwo, Hidayat, A. N. Project Based Learning Model Based on Local Wisdom in Citizenship Education Courses to Prevent Radicalism among Students. Psychology and Education. 2021; 58(3): 2268-2272.

[8] Syahrul, S. Integrating Pluralism and Multicultural Education to Prevent Radicalism at Universitas Muhammadiyah Kupang. Edukasia. 2021; 16(1): 1-14.

[9] Wahyudin, D. Peace Education Curriculum in the Context of Education Sustainable Development (ESD). Journal of Sustainable Development Education and Research (JESDR). 2018; 2(1):21-31.

Bachri BS. Meyakinkan Validitas Data Melalui Triangulasi Pada Data Kualitatitf. Jurnal Teknologi Pendidikan. 2010; 10(1): 46-62. 